\title{
Technical Note: A mobile sea-going mesocosm system - new opportunities for ocean change research
}

\author{
U. Riebesell, J. Czerny, K. von Bröckel, T. Boxhammer, J. Büdenbender, M. Deckelnick, M. Fischer, D. Hoffmann, \\ S. A. Krug, U. Lentz, A. Ludwig, R. Muche, and K. G. Schulz \\ GEOMAR Helmholtz-Zentrum für Ozeanforschung Kiel, 24105 Kiel, Germany
}

Correspondence to: U. Riebesell (uriebesell@geomar.de)

Received: 23 August 2012 - Published in Biogeosciences Discuss.: 19 September 2012

Revised: 25 February 2013 - Accepted: 26 February 2013 - Published: 19 March 2013

\begin{abstract}
One of the great challenges in ocean change research is to understand and forecast the effects of environmental changes on pelagic communities and the associated impacts on biogeochemical cycling. Mesocosms, experimental enclosures designed to approximate natural conditions, and in which environmental factors can be manipulated and closely monitored, provide a powerful tool to close the gap between small-scale laboratory experiments and observational and correlative approaches applied in field surveys. Existing pelagic mesocosm systems are stationary and/or restricted to well-protected waters. To allow mesocosm experimentation in a range of hydrographic conditions and in areas considered most sensitive to ocean change, we developed a mobile sea-going mesocosm facility, the Kiel Off-Shore Mesocosms for Future Ocean Simulations (KOSMOS). The KOSMOS platform, which can be transported and deployed by mid-sized research vessels, is designed for operation in moored and free-floating mode under low to moderate wave conditions (up to $2.5 \mathrm{~m}$ wave heights). It encloses a water column $2 \mathrm{~m}$ in diameter and 15 to $25 \mathrm{~m}$ deep $\left(\sim 50-75 \mathrm{~m}^{3}\right.$ in volume) without disrupting the vertical structure or disturbing the enclosed plankton community. Several new developments in mesocosm design and operation were implemented to (i) minimize differences in starting conditions between mesocosms, (ii) allow for extended experimental duration, (iii) precisely determine the mesocosm volume, (iv) determine air-sea gas exchange, and (v) perform mass balance calculations. After multiple test runs in the Baltic Sea, which resulted in continuous improvement of the design and handling, the KOSMOS platform successfully completed its first full-scale experiment in the high Arctic off Svalbard $\left(78^{\circ} 56.2^{\prime} \mathrm{N}, 11^{\circ} 53.6^{\prime} \mathrm{E}\right)$ in June/July 2010 . The study, which
\end{abstract}

was conducted in the framework of the European Project on Ocean Acidification (EPOCA), focused on the effects of ocean acidification on a natural plankton community and its impacts on biogeochemical cycling and air-sea exchange of climate-relevant gases. This manuscript describes the mesocosm hardware, its deployment and handling, $\mathrm{CO}_{2}$ manipulation, sampling and cleaning, including some further modifications conducted based on the experiences gained during this study.

\section{Introduction}

Of the more than 260 scientific papers published until now on ocean acidification and its impacts on marine life less than $5 \%$ have been conducted on communities or ecosystems, with the vast majority of studies performed on individual species (Gattuso and Hansson, 2011). Extrapolating from organism-based effects to community and ecosystem impacts is difficult, because the observed responses are typically obtained in the absence of competition, trophic interactions, and with low or no genetic diversity (Riebesell and Tortell, 2011). For the same reasons parameterizations of biological processes in ecosystem and biogeochemical models based on physiological responses of individual organisms are problematic. In benthic systems, natural high $\mathrm{CO}_{2}$ environments, such as $\mathrm{CO}_{2}$-venting sites, provide a powerful test bed to assess effects of ocean acidification at the community and ecosystem level. Studies at volcanic $\mathrm{CO}_{2}$ vents have revealed drastic changes in benthic community composition and biodiversity when compared to adjacent areas not exposed to high $\mathrm{CO}_{2}$ (Barry et al., 2011). Because of 
lateral advection and mixing of water masses, $\mathrm{CO}_{2}$-venting sites generally do not provide useful testing grounds to study ocean acidification impacts on pelagic communities (Riebesell, 2008). Oceanographic transects along natural $\mathrm{CO}_{2}$ gradients, e.g. from temperate to high-latitude waters (Charalampopoulou et al., 2011) or from recently upwelled high$\mathrm{CO}_{2}$ waters downstream towards lower- $\mathrm{CO}_{2}$ waters (Beaufort et al., 2011), offer the opportunity for community-level comparisons. Because of the many other environmental factors varying in concert with $\mathrm{CO}_{2}$, the interpretation of observed biotic differences along those gradients is complex.

For pelagic systems mesocosms provide a powerful approach to maintain a natural community under close-tonatural self-sustaining conditions, taking into account relevant aspects from "the real world" such as indirect effects, biological compensation and recovery, and ecosystem resilience, which commonly are not accounted for in smallscale laboratory experiments (Riebesell et al., 2010). The mesocosm approach is therefore often considered the experimental ecosystem closest to the "real world", without losing the advantage of reliable reference conditions and replication (Petersen et al., 2003). The main advantages unique to mesocosm experimentation are as follows:

1. The ability to investigate community dynamics of three or more levels for an extended period of time.

2. The ability to measure the pools and fluxes of bio-active and particle reactive elements and compounds and to perform mass balance calculations in complex systems.

3. The ability to study interactions of ecosystem dynamics and biogeochemical processes under experimental conditions.

4. The ability to bring together scientists from a variety of disciplines, ranging from, e.g., molecular and evolutionary biology, ecophysiology, marine ecology and biogeochemistry to marine and atmospheric chemistry.

It needs to be acknowledged, however, that some constraints of enclosures are to be considered when extrapolating mesocosm results to natural systems (see Riebesell et al., 2010, for a review). Enclosures of all kinds are inherently limited in their ability to include higher trophic levels (e.g. fish, seabirds and mammals), and to approximate vertical mixing of water column and small-scale shear occurring in nature (Menzel and Steele, 1978; Carpenter, 1996). Enclosure effects may also influence food web dynamics to varying degrees, creating trophic interactions that can differ with mesocosm dimension and which may deviate from those of the natural system intended to be mimicked (Kuiper et al., 1983; French and Watts, 1989, Petersen et al., 2009). Despite these difficulties and the intense debate they have spurred over the past decades (e.g. Pilson and Nixon, 1980; Brockmann, 1990; Drenner and Mazumber, 1999), mesocosm enclosure studies still remain the most generally applicable means to experimentally manipulate and repeatedly sample multi-trophic planktonic communities.

Considering the wide range of topics in ocean change research where mesocosm experimentation could greatly advance our science, there are surprisingly few marine mesocosm facilities in operation. Moreover, existing facilities are either stationary or confined to well-protected waters, limiting their scope of application. Here we describe a newly developed sea-going mesocosm facility which can be used in moored and free-floating mode under low to moderate wave conditions (up to $2.5 \mathrm{~m}$ wave heights). The new design in combination with new developments in mesocosm handling and sampling are intended to optimize mesocosm performance, prolong the duration of mesocosm experiments, and perform mass balance calculations by accounting for all relevant pools and fluxes of elements and compounds of interest.

\section{Material and methods}

Most of the following description relates to the 2010 experiment off Svalbard. The corresponding sections are written in past tense. Some aspects of the mesocosm hardware and handling used in 2010 were modified in subsequent experiments. To avoid providing detailed descriptions of the KOSMOS approach for each new experiment, we have included descriptions of those modifications in this manuscript. To distinguish between aspects specific for the 2010 experiment and those applicable to KOSMOS hardware and handling in general, we will use past tense in the case of the former and present tense for the latter.

\subsection{Mesocosm hardware}

The Kiel Off-Shore Mesocosms for Future Ocean Simulations (KOSMOS) consist of 9 mesocosm units, which are operated independently. Each unit comprises a floatation frame, the mesocosm bag, a bottom shutter and sediment trap, a dome-shaped hood on top of the floatation frame, weights at the bottom of the floatation frame and the lower end of the bags to maintain an upright position when exposed to wind and wave activity, and various ropes needed for mesocosm operation. The total weight of each KOSMOS unit, including all components described below, is approximately 1.7 tons.

\subsection{Floatation frame}

The KOSMOS floatation frame consists of six $7.5 \mathrm{~m}$-long, $30 \mathrm{~cm}$-diameter closed glass fibre tubes which are fixed to a steel structure in the lower part and by a steel metal ring at the top end. Steel weights are attached to the horizontal junctions at the bottom of the steel structure. The diameter of the glass fibre tubes, which generate the buoyancy, is reduced at and above the waterline to lower the up- and downward movement of the floatation frame due to wave action. 


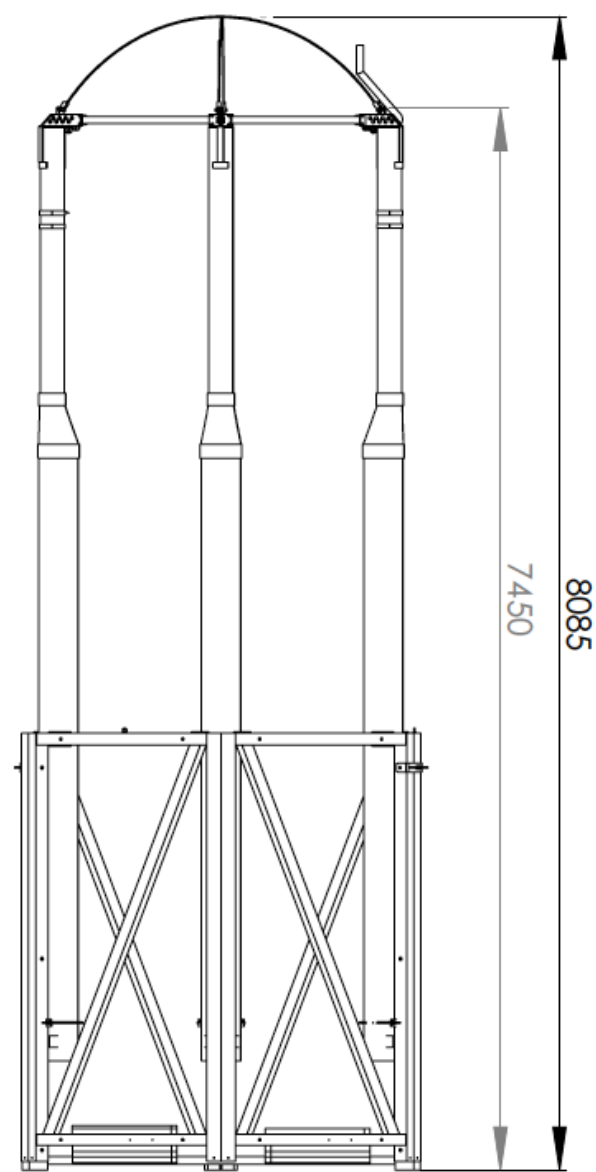

Fig. 1. Drawing of floatation frame with steel structure (lower part), glass fibre tubes for buoyancy, and steel ring at top, holding the dome-shaped PVC hoods. The tapering of the tubes in the abovesurface section reduces buoyancy changes due to wave activity. Size indications in $\mathrm{mm}$.

A dome-shaped roof made of polyvinyl chloride (PVC) covered with metal spikes is mounted on top of the floatation frame to reduce precipitation into the mesocosms and prevent seabirds from landing on the frame and defecating into the enclosures. The PCV foil has ca. $80 \%$ light transparency in the spectral range $>400 \mathrm{~nm}$ wavelength. Below $400 \mathrm{~nm}$ the transparency strongly decreases, largely precluding the penetration of UV light. A flashlight with light sensor, solar panels and radar reflector is mounted on top of the frame, intended to alert passing ships. A set of clamps on either side of the frame above the waterline serves to fix various ropes needed to unfold, fix and operate the mesocosm enclosures (see mesocosm filling below). At the time of deployment the mesocosm bag is folded in a pack positioned above the water line (as displayed in Fig. 1).

\subsection{Mesocosm bags}

The enclosure bags are made of thermoplastic polyurethane (TPU) with a thickness of $1 \mathrm{~mm}$ in the upper $7 \mathrm{~m}$ and $0.5 \mathrm{~mm}$ below that. The bag diameter is $2 \mathrm{~m}$. The length of the bag can be selected according to the scientific question and the conditions at the deployment location. For the 2010 experiment a total length of $17 \mathrm{~m}, 2 \mathrm{~m}$ above and $15 \mathrm{~m}$ below the water line, with a volume of approximately $50 \mathrm{~m}^{3}$, was chosen. Follow-up experiments in the Raunefjord south of Bergen, Norway, in June/July 2011 used bag total lengths of $25 \mathrm{~m}$, and off Hawaii in November/December 2011 and in the Finnish archipelago off Tvärminne in June to August 2012 $19 \mathrm{~m}$ bag lengths. To maintain an approximately cylindrical shape of the mesocosm bags, rings of $2 \mathrm{~m}$ inner diameter made of $4 \mathrm{~cm}$ polyethylene pipes are positioned every $2 \mathrm{~m}$ in ring-shaped pockets made of TPU foil fixed onto the outside of the enclosure bag by high-frequency welding (Fig. 2).

Measurements of light intensities taken in parallel inside the mesocosms and outside in the fjord yielded similar surface layer light intensities and similar depth profiles in the PAR spectrum (see also Schulz et al., 2013). Light transparency measurements of the TPU foil revealed nearly $100 \%$ absorbance of UV light. This together with the low light transparency below $400 \mathrm{~nm}$ of the PVC roof resulted in negligible UV light intensities inside the mesocosms.

\subsection{Bottom shutter and sediment trap}

At the bottom of the enclosure bag a steel ring holds two semi-circle plates made of $10 \mathrm{~mm}$-thick Makrolon ${ }^{\circledR}$. The plates are in upright position to allow water to enter the mesocosm bags during the lowering and unfolding of the bags (Fig. 3, left panel). A 2 m-long funnel-shaped sediment trap with a mouth of the same diameter as the mesocosm bag is connected to one of the bottom lids. It is tightly folded and attached between the bottom plates and unfolds and stretches automatically through an air-filled ring at the upper end of the funnel immediately after the bottom plates are closed (Fig. 3, right panel). A silicon tube connects to the lower end of the funnel from below the bottom lids and extends to the water surface on the outside of the mesocosms (Fig. 4). Material collected in the sediment trap is regularly sampled via this tube, using a manual vacuum pump system. Processing of the samples included sub-sampling for zooplankton counting, followed by concentrating the residual sediment material, freeze-drying, grinding and homogenizing for subsequent chemical analysis.

The sediment trap as described here created a "dead volume" underneath the funnel of approximately $8 \%$ of the enclosure volume. Because this water gradually exchanged with the rest of the enclosed water over one to two days, there was a dilution effect after experimental manipulations such as $\mathrm{CO}_{2}$ enrichment and nutrient addition. This complicated determining precisely the start value of the applied 


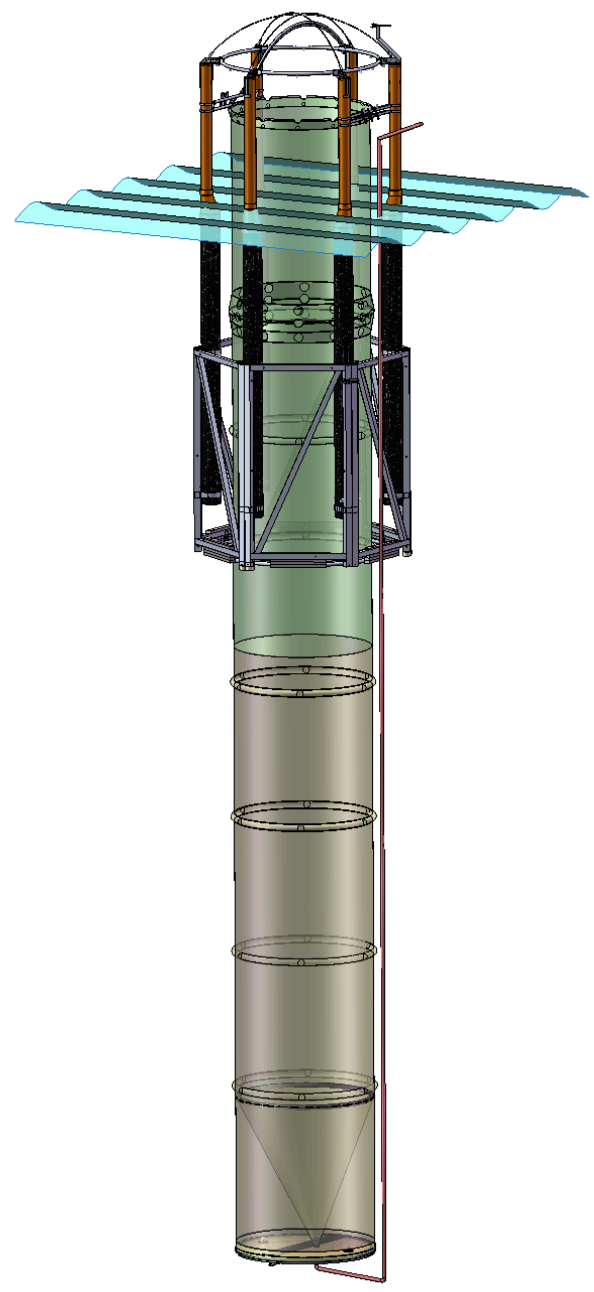

Fig. 2. Sketch of floatation frame with unfolded TPU enclosure bag; different colouring of the light-transparent bag indicates difference in TPU foil thickness: green, $1 \mathrm{~mm}$; brown, $0.5 \mathrm{~mm}$. The blue rippled plane represents the water line. At the bottom of the bag above the bottom plate the funnel-shaped sediment trap is indicated. The red line extending from the tip of the sediment trap to the water surface represents the tube used for sampling of sedimented matter.

manipulation. To avoid the dilution effect, a new sediment trap was designed after the 2010 campaign and applied in all later studies. This new trap is connected to the bottom of the mesocosm through a flange (Fig. 4). Mounted by divers after the filling of the bag, the trap closes off the mesocosm at the bottom end.

\subsection{Mooring and deployment}

The mesocosms can be operated in moored or free-floating mode. When moored, the mesocosms are deployed in groups of three at a distance of 30 to $50 \mathrm{~m}$ between mesocosm units (Fig. 5). Units of each group are connected to each other through ropes fixed to the floating frames at $2.5 \mathrm{~m}$ water depth. The groups are separated by approximately
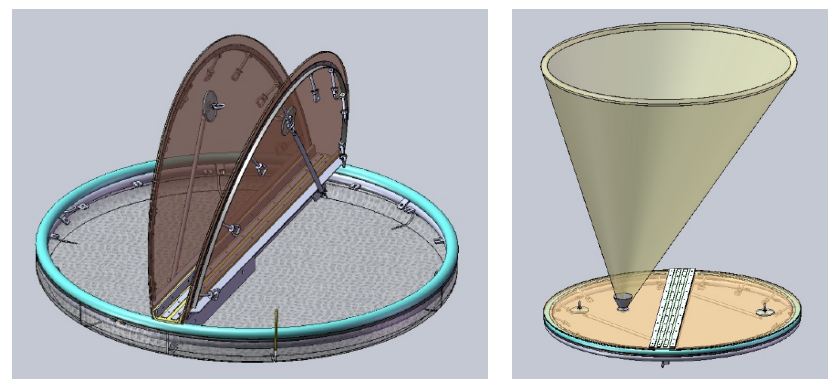

Fig. 3. Sketches of bottom plate. Left: lids in upright position, as applied during filling of the enclosure bags. A removable net (grey shaded area) with a mesh size of $3 \mathrm{~mm}$ is mounted below the bottom ring. Each bottom plate is equipped with 8 screws for tightening the lids after closing. Right: bottom plate in closed position with unfolded sediment trap.
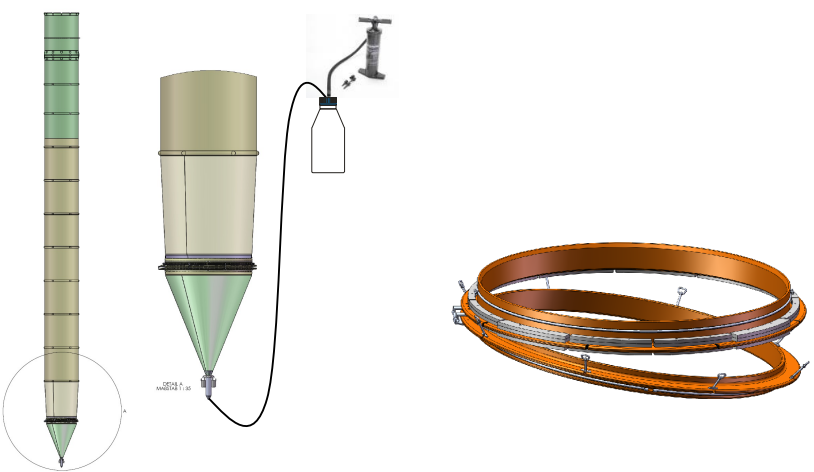

Fig. 4. Left: sketch of sediment trap used in 2011 and 2012 campaigns. The funnel-shaped trap made of TPU foil is connected to the bottom of the enclosure bag via a flange (right panel). Note the tapering of the lowest section of the mesocosm bag. Sampling of sedimented matter is achieved via a silicon tube which connects to a $5 \mathrm{~L}$ sampling flask and a hand-operated vacuum pump. Right: flange ring made of laminated fibreglass to attach the external sediment trap to the lower end of the enclosure bag. The upper ring (connected to the bag) is equipped with steel weights to facilitate the sinking of the enclosure bag during mesocosm filling and to keep the bag in vertical position when exposed to currents. Bag and sediment trap are fixed to the upper and lower flanges by stainless steel clamps pressing the TPU foil in notches. Upper and lower flanges are connected with eight screws and sealed with a silicon rubber fitting.

$50 \mathrm{~m}$ between each group and anchored on both ends with weights (1.2 tonnes) consisting of railway wheels. Buoys are mounted between mesocosms and the anchor weights to ensure that the downward pull generated by strong currents is absorbed by the buoys rather than acting directly on the mesocosms. When operated in moored mode, the water currents acting on the mesocosms should not exceed 0.5 knots to avoid strong vertical deflection of the mesocosm bags and wearing on the ropes. In free-floating mode, as applied in the 2011 campaign off Hawaii, a drogue was connected to one 

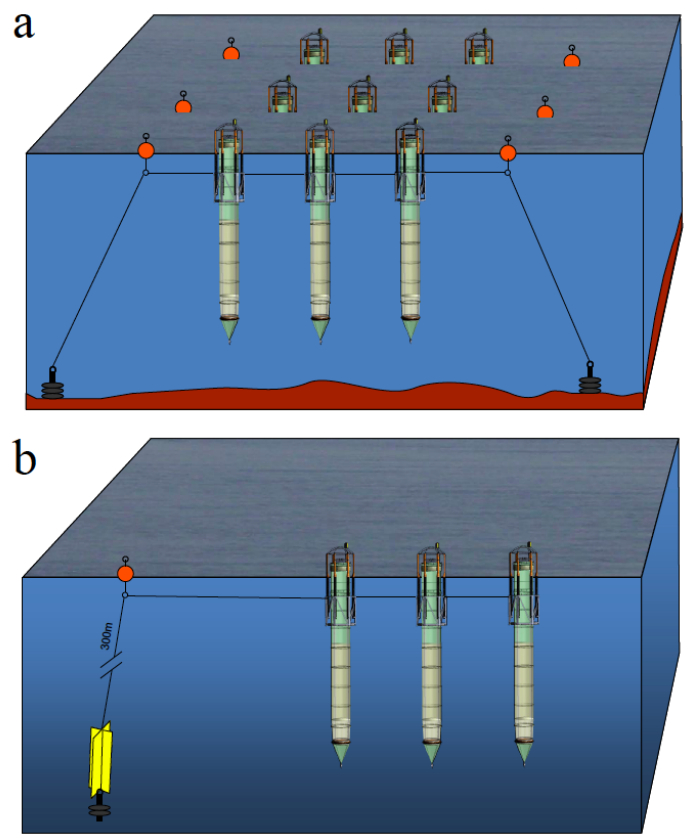

Fig. 5. Schematic drawing of the two modes of mesocosm operation: (a) mesocosms in moored mode in packs of three with anchor weight at each end as used in the Svalbard 2010 study; (b) mesocosms in free-floating mode connected to a weighted drogue hanging from a buoy at $150 \mathrm{~m}$ water depth. This approach was first tested in the 2011 campaign off Hawaii.

end of the three mesocosms. The weighted drogue was hanging from a large buoy at 150 water depth and thereby was exposed to water currents deviating from those at the surface. It served to generate a steady drag at one end of the mesocosm array in order to keep the mesocosms apart and in a straight line. In this mode there is no limit on the acceptable speed of water currents.

\subsection{Filling and closing}

The filling of the mesocosms started after all mesocosms were moored in position. For this the enclosure bags were untied at the bottom, allowing the weighted lower end of the bags to sink through the water column with open shutters until the bags were completely unfolded. With this approach the mesocosms were filled with minimal disturbance of the enclosed water body. To avoid capturing large organisms (e.g. fish, jelly fish) a removable net with a mesh size of $3 \mathrm{~mm}$ was mounted across the bottom opening. Several teams were involved in filling the mesocosms in parallel in close succession to reduce the effect of changing water masses due to lateral advection during the filling process. Nevertheless, because the mesocosms were not all filled simultaneously and because of possible small-scale patchiness in the plankton community (i.e. smaller than the distance between individual mesocosms), there was a risk of differences between enclosed water bodies in terms of seawater chemistry and plankton community abundance and composition. This could have caused large inter-mesocosm variability during the experiment. To minimize differences in starting conditions between enclosed water bodies, the mesocosms were left open for free exchange with the surrounding water for $48 \mathrm{~h}$ after filling. For this the bottom shutters were kept open and the upper part of the bags lowered to $1.5 \mathrm{~m}$ below the water surface with the top and bottom opening covered with a net of $3 \mathrm{~mm}$ mesh size. Test runs during previous years with dyes injected into the mesocosms indicated that, depending on bag length and current speed, a complete exchange of the enclosed water body occurs within 2-3 days. By gradually exchanging the enclosed and surrounding water masses, it is insured that spatial patchiness is averaged out over time. While the mesocosms were open for water exchange, frequent measurements were conducted for several chemical and biological parameters to test for differences between mesocosms. The absence of detectable differences in these parameters was a precondition for mesocosm closing.

The exchange between mesocosms and surrounding water was terminated by lifting the upper parts of the bags above the surface and having divers close the bottom plates. At this point the top and bottom nets are removed. With the closing of the bottom shutters the sediment trap, folded and fixed between the two bottom plates, unfolds and rises through an air-filled ring until fully extended (Figs. 2 and 3). The closing of the mesocosms marks the beginning of the experimental period.

As described above, bottom plate and internal sediment trap were replaced by a flange-connected external sediment trap after the 2010 campaign. In the following campaigns the sediment traps were put in place by divers after the full extension of the enclosure bags. In this new design the sediment trap also has the function of closing off the bottom of the bags. The sediment trap is put in place in two steps: initially it is connected by a hinge integrated in the flange (see Fig. 7, left side of the flange). At this stage the sediment trap is hanging parallel to the mesocosm bag, held by the hinge and tied to the first support ring. In a second step (e.g. on the following day), divers turn the lower flange ring in horizontal position to fully connect with the upper flange ring, thereby expending the TPU foil forming the funnel of the sediment trap. The two flange rings are tightly connected by 8 screws. As before, the mesocosms are closed by divers after 2-3 days of open exchange between mesocosm and surrounding water. After mounting of the sediment trap, three 5 $\mathrm{kg}$ weights are mounted at its lower end to keep the funnel stretched. A hose connected to the bottom of the funnel and reaching above the water surface is used for sampling of the sedimented material (Fig. 4). 


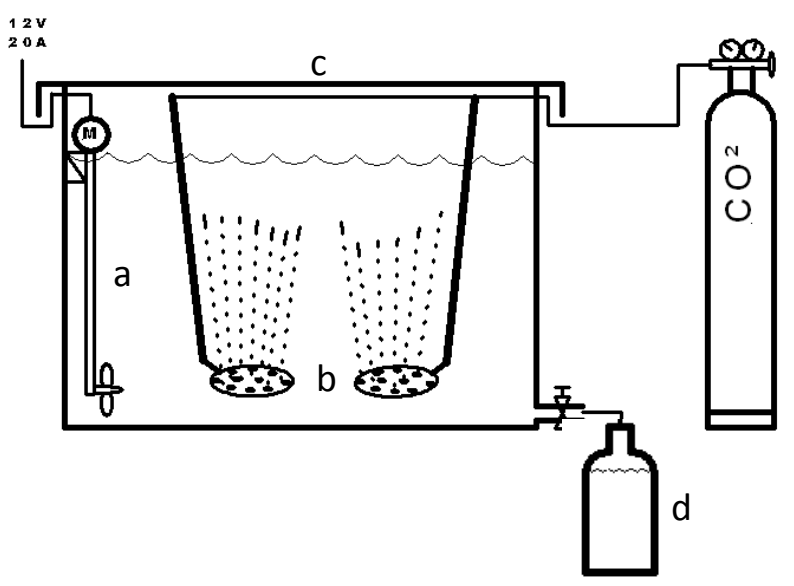

Fig. 6. Schematic drawing of the setup used for the preparation of $\mathrm{CO}_{2}$-enriched water. An electric outboard motor (a) continuously mixed the water in the $1.4 \mathrm{~m}^{3}$ polypropylene tank which was tightly closed by a lid (c). Two large aerating disks (b) produced fine bubbles ensuring relatively low gas consumption. After aeration, the $\mathrm{CO}_{2}$-enriched water was filled into $25 \mathrm{~L}$ polycarbonate carboys (d) for transport and quantitative addition into the mesocosms, using the "spider".

\section{7 $\mathrm{CO}_{2}$ and nutrient manipulation}

$\mathrm{CO}_{2}$ enrichment was carried out by adding $\mathrm{CO}_{2}$-enriched fjord water into the mesocosms. The addition of $\mathrm{CO}_{2}$ enriched seawater increases dissolved inorganic carbon (DIC) while leaving total alkalinity constant, perfectly mimicking on-going ocean acidification (cf. Schulz et al., 2009, Gattuso et al., 2010). With 9 mesocosms available for this study, the choice was made to apply a $\mathrm{CO}_{2}$ gradient with 8 different $\mathrm{CO}_{2}$ levels, duplicating only the ambient $\mathrm{CO}_{2}$ conditions without $\mathrm{CO}_{2}$ manipulation (considered as control). This approach involves the use of regression statistics for assessment of possible $\mathrm{CO}_{2}$ effects. This choice was made for the following reasons:

(a) Because of the low number of experimental units available and considering the risk of losing one or several mesocosms (e.g. due to damage by ice floats), a $\mathrm{CO}_{2}$-gradient approach carries a lower risk of failure compared to a replicated approach (e.g. $3 \mathrm{CO}_{2}$ treatments with triplicates each) relying on ANOVA statistics.

(b) If there is a threshold level for any of the $\mathrm{CO}_{2} / \mathrm{pH}$ sensitive processes, a $\mathrm{CO}_{2}$-gradient approach has a higher chance of detecting it.

(c) With a $\mathrm{CO}_{2}$-gradient approach the opportunity arises to include one or two $\mathrm{CO}_{2}$ levels outside the range recommended for ocean acidification perturbation experiments (Barry et al., 2010), which would be more difficult to justify if such extreme levels were replicated.

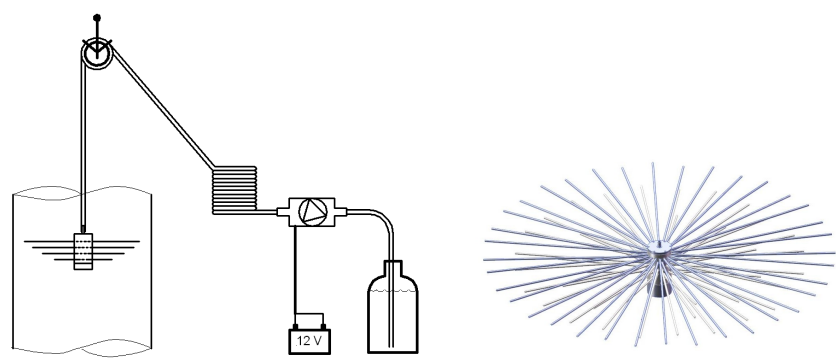

Fig. 7. Left: sketch of setup used for $\mathrm{CO}_{2}$ manipulation. $\mathrm{CO}_{2-}$ enriched water is pumped from $25 \mathrm{~L}$ carboys via a garden hose into the "spider", which is gradually moved up and down over the entire length of the enclosure bag by manually heaving and hauling it via a pulley fixed above the centre of the enclosure bags underneath the hood. Right: the dispersion device ("spider") is composed of a polyoxymethylen body weighted with a $5 \mathrm{~kg}$ stainless steel stand. It has 84 jets $(\varnothing 500 \mu \mathrm{m})$ of which 78 are equipped with elastic acryl branches of different lengths distributing the liquid evenly over a horizontal cross-section of the mesocosm. The diameter of the jets serves as a bottleneck, releasing $\sim 80 \mathrm{~mL} \mathrm{~min}^{-1}$ of liquid dispensed through every jet irrespective of the length of the branch connected to it.

(d) Although $\mathrm{CO}_{2}$ manipulation is relatively straightforward, it is challenging to precisely achieve the targeted $\mathrm{CO}_{2}$ levels. While critical in a replicated approach, in a $\mathrm{CO}_{2}$-gradient approach deviations from the targeted $\mathrm{CO}_{2}$ levels can be tolerated.

It was decided to replicate the ambient $\mathrm{CO}_{2}$ level (control treatment) in order to minimize the risk of completing the experiment with no control in case of losing one or several mesocosm units. The different $\mathrm{CO}_{2}$ levels were randomly interspersed among the 9 mesocosms (cf. Riebesell et al., 2010).

The $\mathrm{CO}_{2}$-enriched seawater was prepared in a $1.4 \mathrm{~m}^{3}$ tank on land filled with filtered (pore size $20 \mu \mathrm{m}$ ) fjord water which was stirred by an electric propeller while aerated with pure $\mathrm{CO}_{2}$ gas for approximately $24 \mathrm{~h}$ (Fig. 6). At this stage the $\mathrm{CO}_{2}$ partial pressure in the water was close to saturation ( $\mathrm{pH} \sim 4.4)$.

The DIC concentration in the $\mathrm{CO}_{2}$-enriched water was calculated based on measurements of total alkalinity, $\mathrm{pH}$ (presented in total scale unless stated otherwise), salinity and temperature, using the computer program $\mathrm{CO}_{2} \mathrm{SYS}$ (Lewis and Wallace, 1997). Based on this the amount of $\mathrm{CO}_{2-}$ enriched water needed to achieve the target $p \mathrm{CO}_{2}$ levels in the different $\mathrm{CO}_{2}$ treatments was calculated. The $\mathrm{CO}_{2}-$ enriched water was filled into $25 \mathrm{~L}$ carboys and transported to the mesocosms. Depending on target $p \mathrm{CO}_{2}$, between 0 and $320 \mathrm{~L}$ (see Schulz et al., 2013) of the $\mathrm{CO}_{2}$-enriched seawater was injected into the mesocosms by means of a membrane pump and a dispensing device (termed "spider"; Fig. 7, right panel). To achieve an even distribution of the $\mathrm{CO}_{2}$ enriched water throughout the mesocosms, the "spider" was 
slowly moved up and down during the injection over the entire length of the enclosure bags (Fig. 7, left panel). Vertical $\mathrm{pH}$ profiles were conducted after $\mathrm{CO}_{2}$ additions to check whether an even distribution was achieved.

The injection of $\mathrm{CO}_{2}$-enriched water was done in steps over 4 consecutive days starting in the afternoon of 6 June (t-1). Two mesocosms served as controls, while 7 mesocosms were manipulated to establish treatments of elevated $p \mathrm{CO}_{2}$ with an initial range of $185-1420 \mu \mathrm{atm}$. Mean values of $p \mathrm{CO}_{2}$ during the experimental period ranged from 175-1085 $\mu$ atm (for details see Bellerby et al., 2012). In mesocosms with no or low addition of $\mathrm{CO}_{2}$-enriched water, similar amounts of filtered fjord water were added in order to apply the same physical perturbation to all mesocosms. Some fine-tuning to reach target $\mathrm{CO}_{2}$ levels was conducted on 11 June (t4), at which time the target $p \mathrm{CO}_{2}$ levels where reached with an offset generally smaller than $\pm 50 \mu \mathrm{atm}$. After this no further $\mathrm{CO}_{2}$ manipulation was done in any of the mesocosms. Because of the slow exchange of water in the "dead volume" below the sediment trap with that in the rest of the enclosure bag, there was a dilution of the initial $\mathrm{CO}_{2}$ enrichment due to mixing of the $\mathrm{CO}_{2}$ manipulated (open bag) and non-manipulated ("dead volume") water during the first couple of days. Budget calculations based on carbonate chemistry measurements starting after $\mathrm{CO}_{2}$ manipulations needed to account for this dilution effect (Czerny et al., 2012a, 2013; de Kluijver et al., 2013; Silyakowa et al., 2013).

In the early morning of 20 June (t13), inorganic nutrients were added using the same dispersion device as described above and shown in Fig. 7 at concentrations of $5 \mu \mathrm{mol} \mathrm{L} \mathrm{L}^{-1}$ $\mathrm{NO}_{3}, 0.32 \mu \mathrm{mol} \mathrm{L}^{-1} \mathrm{PO}_{4}$, and $2.5 \mu \mathrm{mol} \mathrm{L}{ }^{-1} \mathrm{Si}$. The precise amounts of inorganic nutrients added to each mesocosm were calculated based on volume determinations conducted for all mesocosms through salt additions on 3 June ( $\mathrm{t} 4$ ) and 11 June (t4). For a detailed description of the volume determination see Czerny et al. (2012b).

Approximately 200 live adult pteropods (Limacina helicina) sampled individually from the fjord were added to each mesocosm during 11-13 June (t4-t6) to study their response to ocean acidification. For unknown reasons the pteropods rapidly disappeared from the water column. Some pteropods were collected in the sediment traps; others were seen by divers accumulating in the dead volume underneath the sediment traps. Very few specimen survived the experiment.

\subsection{Cleaning of the mesocosm walls}

To estimate the contribution of wall growth to the overall production and accumulation of particular organic matter $(\mathrm{POM})$ in the mesocosms, the inside of the enclosure bags was cleaned with a ring-shaped brush on 7 July (t30). Various biological parameters were determined on suspended particulate matter immediately before and after brushing of

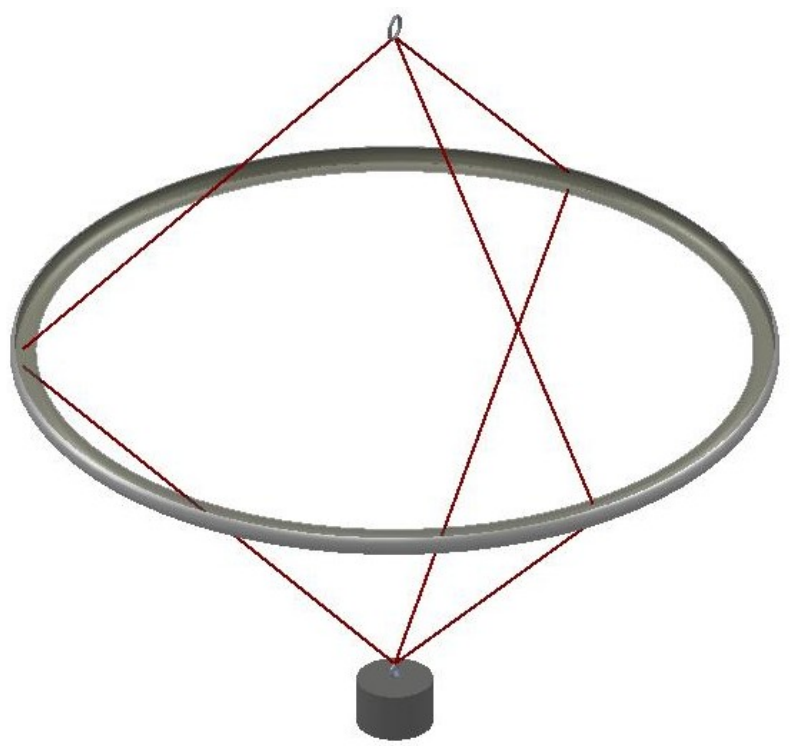

Fig. 8. Ring-shaped brush used for cleaning the inside of the enclosure walls. The brush is pulled downwards by a weight attached by ropes below the ring and pulled upwards manually by a rope run over a pulley fixed above the centre of the enclosure bags underneath the hood. In follow-up experiments the brush was replaced by a double-bladed wiper.

the walls to quantify the amount of biomass released into the water column. As reported in Czerny et al. (2012a) on average $16 \%$ of the nitrate and $32 \%$ of the phosphate added on t13 had accumulated on the mesocosm walls due to biofilm formation on $\mathrm{t} 30$. In follow-up campaigns, the formation of biofilms on the inside of the enclosure bags (wall growth) was prevented by regular cleaning (once per week) with a ring-shaped, double-bladed wiper using a similar configuration as depicted in Fig. 8.

\subsection{Sampling}

Vertical profiles of temperature, conductivity, $\mathrm{pH}$, oxygen, fluorescence, turbidity and light intensity were taken daily in each mesocosm and the surrounding water between 14:00 and 16:00 LT with a CTD60M (Sun and Sea Technologies). Sampling of seawater from the mesocosms was conducted with a depth-integrating water sampler (Hydro-Bios). The sampler is equipped with a pressure-controlled motor and continuously collects water ( $5 \mathrm{~L}$ volume) while being lowered from the surface to $12 \mathrm{~m}$ depth. Samples were collected in the morning between 9:00 and 11:00 In addition discrete samples were taken at fixed depths using Niskin bottles and pumping systems with sampling tubes lowered into the mesocosms (for details see M\&M in the corresponding manuscripts). For measurements of DIC, total alkalinity, $\mathrm{N}_{2} \mathrm{O}$, inorganic nutrients, dissolved organic matter, volatile organic compounds, oxygen incubations, and other samples sensitive for contamination and gas exchange, subsamples 
Table 1. Starting conditions in the nine mesocosms (M1-M9) and the surrounding fjord water. Data for salinity, pH and oxygen concentration (determined in situ with a CTD equipped with $\mathrm{pH}$ and oxygen sensors) for day $\mathrm{t}-4$, all others for day t0. $\mathrm{pH}$ is in total scale, concentrations for oxygen, nitrate, ammonium, phosphate and silicate are in $\mu \mathrm{mol} \mathrm{L}{ }^{-1}$. See Schulz et al. (2013) for details on the methodologies.

\begin{tabular}{lrrrrrrrrrr}
\hline & M1 & M2 & M3 & M4 & M5 & M6 & M7 & M8 & M9 & Fjord \\
\hline Salinity & 33.90 & 33.90 & 33.90 & 33.91 & 33.91 & 33.90 & 33.90 & 33.93 & 33.93 & 33.58 \\
pH & 8.36 & 8.36 & 8.37 & 8.35 & 8.36 & 8.35 & 8.37 & 8.37 & 8.39 & 8.36 \\
$\mathrm{O}_{2}$ & 466 & 462 & 461 & 462 & 460 & 460 & 462 & 463 & 466 & 476 \\
$\mathrm{NO}_{3}^{-}$ & 0.03 & 0.03 & 0.02 & 0.03 & 0.01 & 0.01 & 0.02 & 0.02 & 0.03 & 0.01 \\
$\mathrm{NH}_{4}^{+}$ & 0.59 & 0.59 & 0.60 & 0.60 & 0.59 & 0.59 & 0.49 & 0.59 & 0.69 & 0.22 \\
$\mathrm{PO}_{4}^{3-}$ & 0.04 & 0.05 & 0.05 & 0.06 & 0.05 & 0.06 & 0.05 & 0.06 & 0.06 & 0.04 \\
$\mathrm{Si}(\mathrm{OH})_{4}$ & 0.15 & 0.16 & 0.15 & 0.17 & 0.12 & 0.12 & 0.12 & 0.10 & 0.12 & 0.23 \\
\hline
\end{tabular}

were taken directly from the depth-integrating samplers in a fixed order. For bulk measurements of suspended particulate matter, photosynthetic pigments, biogenic silica, phytoand microzooplankton abundance and composition, and various other components (see $\mathrm{M} \& \mathrm{M}$ in the corresponding manuscripts), the depth-integrated samples were transferred to $10 \mathrm{~L}$ polyethylene containers which were kept in a dark cold room at in situ temperature for later subsampling.

Net hauls were done about once a week (for details see Niehoff et al., 2013). To minimize the effect of zooplankton catches on the plankton abundance and composition, the cross-sectional area sampled by the sum of all net hauls conducted over the course of the experiment was kept to less than one-sixth of the total cross-sectional area of the enclosure bags.

All sampling gear and sensors were plunged into fjord water next to the sampling boats before being deployed in the mesocosms to avoid contamination by adhering materials. All instruments were cleaned with fresh water when returning to land.

\section{Results}

A mesocosm $\mathrm{CO}_{2}$-enrichment experiment was conducted in Kongsfjorden on the north-west coast of Spitsbergen (Fig. 9) between 31 May and 8 July 2010. Nine sea-going mesocosms were loaded in Kiel and deployed on the southern shore of Kongsfjorden near Ny-Ålesund at $78^{\circ} 56.2^{\prime} \mathrm{N}$ und $11^{\circ} 53.6^{\prime} \mathrm{E}$ (Fig. 10) by M/V Esperanza of Greenpeace International on 31 May (t-7). Before mesocosm deployment mooring weights were laid out by R/V Viking Explorer of the University Centre in Svalbard (UNIS). Upon deployment the mesocosms were towed to the mooring site by small boats and tied in three groups of three mesocosms each as indicated in Fig. 10.

\subsection{Conditions in the fjord}

At the time of mesocosm deployment Kongsfjorden off $\mathrm{Ny}$ Ålesund was ice-free, while parts of the inner fjord were covered by sea ice. During the course of the study, the sea ice broke off and the glaciers surrounding Kongsfjorden started to calve. Floats of sea ice and glacier ice drifted towards the mouth of the fjord starting in mid-June. Most of the ice transport occurred along the northern side of the fjord, i.e. on the opposite side of the mesocosm mooring, following the general current pattern in the fjord system. At times of persistent north to north-east winds some ice floats occasionally drifted towards the mesocosm array. A $24 \mathrm{~h}$ ice watch was on duty for the duration of the experiment. In a few cases ice floats needed to be pushed out of their path by small boats to avoid collision with the mesocosms.

The initial $p \mathrm{CO}_{2}$ of the ambient water in the fjord was $\sim 175 \mu \mathrm{atm}$, corresponding to a $\mathrm{pH}$ of $\sim 8.3$ (Bellerby et al., 2012). Concentrations of mineral nutrients in the water were close to detection limit at the beginning of the experiment $\left(0.11 \mu \mathrm{mol} \mathrm{L}^{-1}\right.$ of nitrate, $0.7 \mu \mathrm{mol} \mathrm{L}^{-1}$ of ammonia, $0.13 \mu \mathrm{mol} \mathrm{L}^{-1}$ of phosphate). Additionally, there were $5.5 \mu \mathrm{mol} \mathrm{L}{ }^{-1}$ of dissolved organic nitrogen, $0.20 \mu \mathrm{mol} \mathrm{kg}{ }^{-1}$ of dissolved organic phosphorus (Schulz et al., 2013) and $75 \mu \mathrm{mol} \mathrm{L}^{-1}$ of dissolved organic carbon (Engel et al., 2013). Reduced $\mathrm{pCO}_{2}$ and inorganic nutrient concentrations as well as increased concentrations of organic carbon, nitrogen and phosphorus indicated a post-bloom situation in the fjord at the start of the experiment.

\subsection{Conditions in the mesocosms}

Comparing the initial conditions after closing of the mesocosms provided an indication of the similarity between bags at the start of the experiment. As indicated in Table 1, the chemical conditions were almost identical in all mesocosms. Small differences between mesocosms and the surrounding fjord water were due to changing water masses in the fjord after closing the bags. Close agreement also exists for phytoplankton biomass and taxonomic composition (Table 2). Differences in group-specific chlorophyll $a$ equiva- 


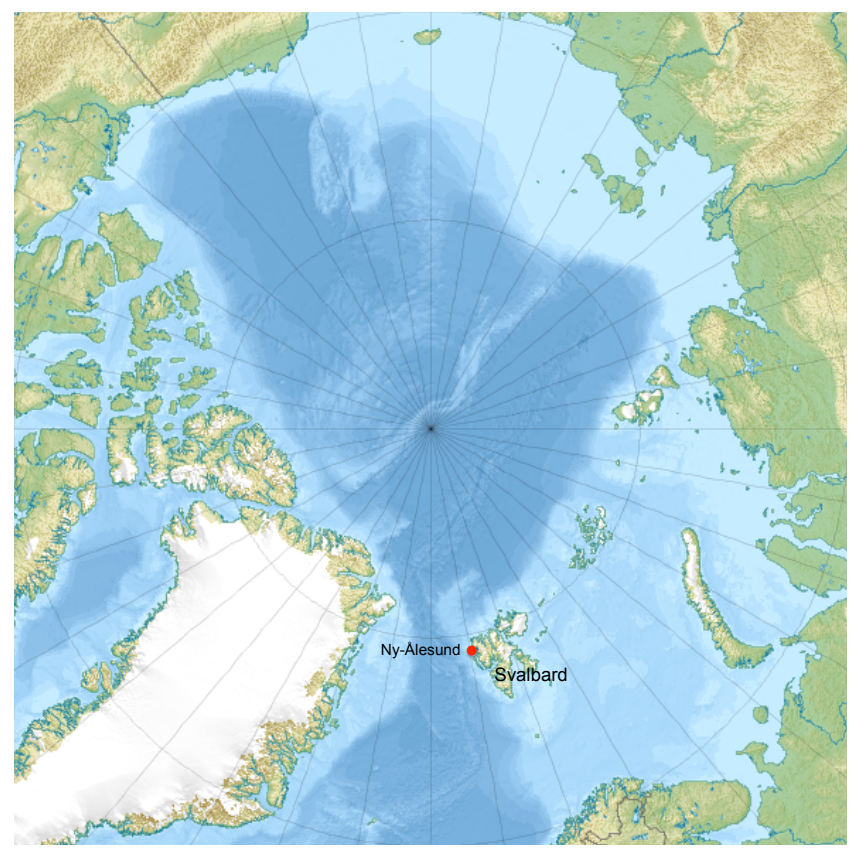

Fig. 9. Map of the Arctic. Red dot denotes the location of the study site (Kongsfjorden, Ny-Ålesund) on the north-west coast of Spitsbergen, the largest island of the Svalbard archipelago. Source: Wikipedia.

lent concentrations between mesocosms for some of the taxonomic groups are more pronounced for those with predominantly large cell sizes combined with low abundances, such as diatoms and dinoflagellates. This difference is most likely due to a sampling bias rather than a true representation of biomass differences in the mesocosms. Almost identical concentrations in all mesocosms are obtained for bacteria and total virus counts (Table 2). Overall, the resemblance in initial values for a variety of chemical and biological parameters suggests proper conditions for the start of the experiment.

\subsection{Temporal development}

A short temporary increase in phytoplankton biomass during the first part of the experiment was probably fuelled by utilization of organic nutrients. Half way through the experiment inorganic nutrients were added to the mesocosms stimulating two additional phytoplankton blooms.

Based on the manipulations carried out over the course of the study, the deployment period is divided into 4 phases, one pre-experimental phase (phase 0 ) and three experimental phases (phases 1-3) as follows:

- phase 0: closing of the mesocosms until end of $\mathrm{CO}_{2}$ manipulation ( $\mathrm{t}-4$ to $\mathrm{t} 4$ ),

- phase 1: end of $\mathrm{CO}_{2}$ manipulation until nutrient addition (t5 to $\mathrm{t} 12$ ),

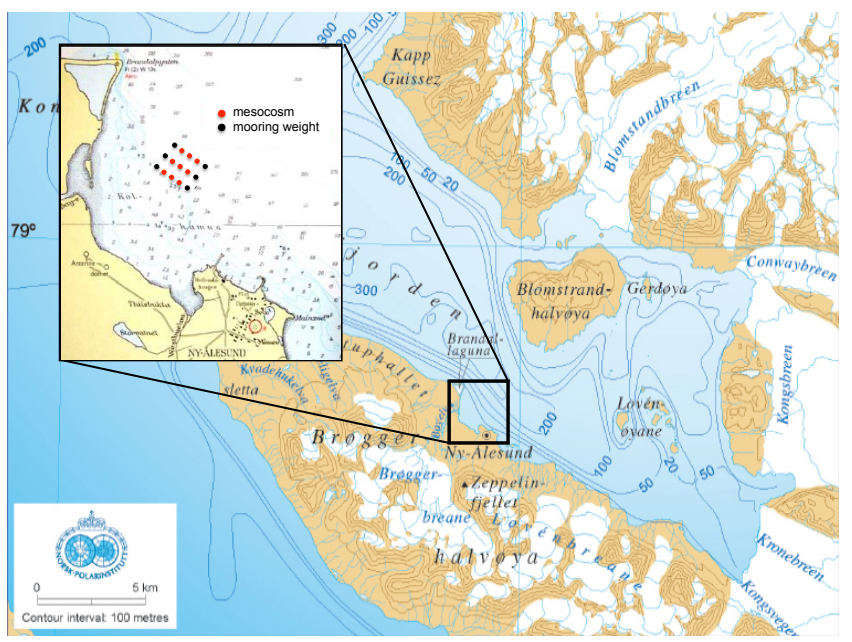

Fig. 10. Map of Kongsfjorden on the north-west coast of Svalbard. Insert shows the study area with the location and orientation of the mesocosm array. Source of map: Norsk Polarinstitutt.

- phase 2: nutrient addition until 2nd chlorophyll minimum (t13 to t21),

- phase 3: 2nd chlorophyll minimum until end of experiment (t22 to t30).

The temporal changes in phytoplankton biomass and community composition observed in the mesocosms follow the same basic trends as those recorded in the waters surrounding the mesocosms (Brussaard et al., 2013; Schulz et al., 2013). Considering that lateral advection caused the water surrounding the mesocosms to exchange rapidly, the close agreement between enclosed and ambient plankton community development seems quite remarkable. This indicates that (1) major trends in plankton development persisted independent of small-scale patchiness in the study area and (2) the enclosed plankton community mimics the natural system reasonably well in terms of major developments in biomass and composition. The close agreement starts to weaken after nutrient addition in the mesocosms.

Aside from providing a comprehensive data set on plankton community responses to ocean acidification and their impacts on biogeochemical cycling, the study offered the opportunity for consistency checks between individual measurements. Particularly enlightening in this respect was the comparison of different approaches determining net community production, which was obtained from bottle incubations measuring $\mathrm{O}_{2}$ production/consumption (Tanaka et al., 2013), estimates of changes in DIC concentration (Silyakowa et al., 2013), and incorporation of ${ }^{13} \mathrm{C}$ tracer added directly into the mesocosms (de Kluijver et al., 2013). These estimates were further compared with ${ }^{14} \mathrm{C}$ incorporation determined in bottle incubations (Engel et al., 2013). While at first sight the different approaches appeared to yield different rates and - more surprisingly - different relationships 
Table 2. Concentrations of chlorophyll $a$ equivalent (in $\mathrm{n} \mathrm{L}^{-1}$ ) for eight taxonomic groups of phytoplankton determined from HPLC measurements using CHEMTAX and bacterial and viral numbers $\left(10^{6} \mathrm{~mL}^{-1}\right)$ measured by flow cytometry for day t0. See Schulz et al. (2013) for details on methodologies. Abbreviations for taxonomic groups refer to prasinophyceae, dinophyceae, crytophyceae, chlorophyceae, cyanophyceae, bacillariophyceae, chrysophyceae, and haptophyceae.

\begin{tabular}{lrrrrrrrrrr}
\hline & M1 & M2 & M3 & M4 & M5 & M6 & M7 & M8 & M9 & Fjord \\
\hline Prasino & 45.8 & 45.8 & 49.1 & 55.5 & 58.6 & 41.5 & 66.8 & 54.5 & 48.9 & 71.5 \\
Dino & 0 & 0.4 & 8.1 & 10.1 & 0 & 27.4 & 8.2 & 13.1 & 4.6 & 12.2 \\
Crypto & 25.2 & 15.5 & 19.7 & 34.6 & 45.6 & 23.1 & 29.5 & 20.7 & 18.3 & 73.3 \\
Chloro & 18.8 & 0 & 0 & 10.0 & 1.4 & 27.2 & 40.8 & 43.5 & 38.3 & 56.9 \\
Cyano & 29.9 & 31.3 & 41.4 & 41.4 & 44.2 & 36.5 & 28.3 & 22.2 & 38.7 & 37.2 \\
Bacillario & 28.4 & 18.5 & 27.7 & 31.4 & 31.8 & 19.6 & 37.2 & 15.3 & 35.7 & 97.8 \\
Chryso & 6.4 & 2.6 & 5.1 & 5.0 & 3.0 & 4.5 & 5.8 & 5.1 & 7.3 & 3.4 \\
Hapto & 28.0 & 65.4 & 28.7 & 35.1 & 51.3 & 25.3 & 16.1 & 25.4 & 19.7 & 18.5 \\
Bacteria & 2.0 & 2.1 & 2.0 & 2.1 & 2.0 & 2.1 & 2.2 & 2.0 & 2.0 & 1.7 \\
Viruses & 61.4 & 53.5 & 54.2 & 58.0 & 48.4 & 53.3 & 49.3 & 58.3 & 53.9 & 52.4 \\
\hline
\end{tabular}

with $\mathrm{CO}_{2}$ concentration, closer examination yielded some interesting insights into the underlying processes and eventually resulted in a coherent interpretation of plankton community responses to ocean acidification (see discussions in references cited above).

\section{Discussions}

\subsection{The study area}

The Arctic Ocean ecosystem is expected to undergo major climate-change-related transformations in the coming decades, ranging from surface layer warming and freshening to enhanced stratification and loss of sea ice. Due to the high $\mathrm{CO}_{2}$ solubility and low carbonate saturation states of its cold surface waters, the Artic Ocean is also considered particularly vulnerable to ocean acidification. If $\mathrm{CO}_{2}$ emissions continue to rise at current rates, half of the Artic Ocean will be undersaturated with respect to calcium carbonate and, therefore, corrosive for calcareous organisms within the next three to four decades (Steinacher et al., 2009). While several Arctic calcifying species have been shown to respond negatively to ocean acidification (e.g. Büdenbender et al., 2011; Comeau et al., 2009; Lischka et al. 2011; Walther et al., 2010; Wood et al., 2011), little is known about possible consequences of ocean acidification at the base of the Arctic food web. The experiment described here was intended as a first attempt at closing this gap by conducting a pelagic meso$\operatorname{cosm} \mathrm{CO}_{2}$-enrichment study in Kongsfjorden on the western coast of Spitsbergen - about 1000 nautical miles south of the North Pole.

Kongsfjorden, an open fjord system without sill, is about $26 \mathrm{~km}$ long and between 4 and $10 \mathrm{~km}$ wide, with a maximum depth of $400 \mathrm{~m}$. The water in Kongsfjorden is influenced by (i) Arctic water masses transported by the coastal current flowing from the Barents Sea over the West Spits- bergen Shelf, (ii) Atlantic water masses coming in with the northbound West Spitsbergen Current, and (iii) freshwater input from calving and melting glaciers as well as precipitation (Hop et al., 2006). Discharge of freshwater and sediments from the adjacent glaciers strongly varies seasonally, peaking in the summer. During winter, the inner part of the fjord is covered by sea ice, with large interannual variability in ice thickness, time of formation and break-up (see Svendsen et al., 2002, for a detailed review of the physical environment of the Kongsfjorden area).

In the fjord the initiation of the phytoplankton spring bloom starts already under ice cover, culminating between April and early June after ice break-up (Eilertsen et al., 1989). The majority of studies conducted on the plankton community in Kongsfjorden focused on the spring period when high nutrient availability and increasing light levels support a substantial fraction of the annual primary production (Iversen and Seuthe, 2011; Seuthe et al., 2011). After the spring bloom, phytoplankton biomass remains moderately high during late spring and summer (Hop et al., 2002). At this time of the year, the plankton community is typically characterized by an efficient microbial loop (Iversen and Seuthe, 2011) that provides inorganic nutrients to phytoplankton and bacteria through rapid organic matter remineralization. These were the conditions encountered at the start of this mesocosm campaign. Accordingly, pico- and nanophytoplankton groups were the dominant autotrophs during the first part of this study (Brussaard et al., 2013). Due to the low seed population of dinoflagellates and diatoms, the dominance of pico- and nano-sized phytoplankton continued even after nutrient addition. The standing stock of microphytoplankton was building up slowly and dominated phytoplankton biomass only towards the end of the experiment (Schulz et al., 2013). 


\subsection{KOSMOS experimental facility}

After a sequence of test runs in free-floating mode conducted in the Baltic Sea in 2006, 2007, and 2008, which led to considerable improvements in the mesocosm hardware and handling, and a four-week trial run in moored mode in 2009, which yielded some novel results on ocean acidification effects during a phytoplankton spring bloom (Schulz and Riebesell, 2012), the Svalbard 2010 campaign was the first full-scale experiment involving nine mesocosm units and covering a broad range of parameters over an extended period of time. Building on the experience gained during this campaign, this new sea-going experimental platform opens up new opportunities for mesocosm experimentation under a variety of hydrographic conditions and geographical locations. Important new features of this facility include

- the enclosure of large volumes $\left(45-75 \mathrm{~m}^{3}\right)$ with minimal disturbance of the enclosed water body and plankton community,

- controlled carbonate chemistry manipulation with minimal agitation of the enclosed water,

- mass balance calculations through precise determination of mesocosm volume by full accounting of all relevant pools and fluxes for key elements (carbon, nitrogen, phosphorus, silica),

- extended experimental duration through routine cleaning of mesocosm walls (preventing extensive wall growth) and regular sediment sampling (preventing release of remineralization products from sedimented matter),

- operation in moored and free-floating mode under low to moderate wave conditions allowing mesocosm experimentation in areas previously not amendable to this kind of experimentation.

This mesocosm campaign, which involved 35 scientists from 12 institutes, provided the opportunity for a highly integrative, multidisciplinary study involving marine engineers, molecular and marine biologists, ecologists, biogeochemists, and marine and atmospheric chemists. By covering a wide range of parameters measured over 35 days ( 4 days prior to and 31 days after the start of $\mathrm{CO}_{2}$ manipulation), it provided a comprehensive data set on pelagic community-level responses to ocean acidification and their impacts on nutrient cycling and air-sea exchange of climate-relevant gases.

Acknowledgements. The design, construction and field testing of the KOSMOS mesocosms was made possible through financial support of GEOMAR and the integrated project SOPRAN (Surface Ocean PRocesses in the ANthropocene) funded by the German
Ministry for Education and Research (BMBF). GEOMAR and SOPRAN provided the KOSMOS facility for the Svalbard 2010 experiment and organized the logistics leading up to and during the experiment. GEOMAR was responsible for deploying the mesocosms, running the experiment and coordinating all scientific aspects before, during and after the experiment. The scientific work is a contribution to the European Project on Ocean Acidification (EPOCA), which received funding from the European Community's Seventh Framework Programme (FP7/2007-2013) under grant agreement no. 211384. Several participants of this study received funding from the European Community's Seventh Framework Programme under grant agreement no 228224, MESOAQUA. We gratefully acknowledge the logistical support of Greenpeace International for its assistance with the transport of the mesocosm facility from Kiel to $\mathrm{Ny}$ Ålesund and back to Kiel. We also thank the captains and crews of M/V Esperanza of Greenpeace and R/V Viking Explorer of the University Centre in Svalbard (UNIS) for assistance during mesocosm transport and during deployment and recovery in Kongsfjorden. We thank the staff of the French-German Arctic Research Base (AWIPEV) at Ny-Ålesund, in particular Marcus Schumacher, for on-site logistical support.

The service charges for this open access publication

have been covered by a Research Centre of the

Helmholtz Association.

Edited by: J. Middelburg

\section{References}

Barry, J. P., Widdicombe, S., and Hall-Spencer, J. M.: Effects of ocean acidification on marine biodiversity and ecosystem function, in: Ocean acidification, edited by: Gattuso J.-P. and Hansson L., Oxford University Press, 192-209, 2010.

Barry, J. P., Tyrrell, T., Hansson, L., Plattner, G.-K., and Gattuso, J.P.: Atmospheric $\mathrm{CO}_{2}$ targets for ocean acidification perturbation experiments, in: Guide to best practices in ocean acidification research and data reporting, edited by: Riebesell, U., Fabry, V., Hansson, L., and Gattuso, J.-P., Office for Official Publications of the European Communities, Luxembourg, 53-66, 2011.

Beaufort, L., Probert, I., de Garidel-Thoron, T., Bendif, E. M., RuizPino, D., Metzl, N., Goyet, C., Buchet, N., Coupel, P., Grelaud, M., Rost, B., Rickaby, R. E. M., and de Vargas, C.: Sensitivity of coccolithophores to carbonate chemistry and ocean acidification, Nature 476, 80-83, 2011.

Bellerby, R. G. J., Silyakova, A., Nondal, G., Slagstad, D., Czerny, J., de Lange, T., and Ludwig, A.: Marine carbonate system evolution during the EPOCA Arctic pelagic ecosystem experiment in the context of simulated Arctic ocean acidification, Biogeosciences Discuss., 9, 15541-15565, doi:10.5194/bgd-9-155412012, 2012.

Brockmann, U.: Pelagic mesocosms: II. Process studies, in: Enclosed experimental marine ecosystems: A review and recommendations, edited by: C. M. Lalli, Springer-Verlag, New York, 81-108, 1990.

Brussaard, C. P. D., Noordeloos, A. A. M., Witte, H., Collenteur, M. C. J., Schulz, K., Ludwig, A., and Riebesell, U.: Arctic microbial community dynamics influenced by elevated $\mathrm{CO}_{2}$ lev- 
els, Biogeosciences, 10, 719-731, doi:10.5194/bg-10-719-2013, 2013.

Büdenbender, J., Riebesell, U., and Form, A.: Calcification of the Arctic coralline red algae Lithothamnion glaciale in response to elevated $\mathrm{CO}_{2}$, Mar. Ecol. Progr. Ser., 441, 79-87, 2011.

Carpenter, S. R.: Microcosm experiments have limited relevance for community and ecosystem ecology, Ecology, 77, 677-680, 1996.

Charalampopoulou, A., Poulton, A. J., Tyrrell, T., and Lucas, M. I.: Irradiance and $\mathrm{pH}$ affect coccolithophore community composition on a transect between the North Sea and the Arctic Ocean, Mar. Ecol. Progr. Ser., 431, 25-43, 2011.

Comeau, S., Gorsky, G., Jeffree, R., Teyssié, J.-L., and Gattuso, J.-P.: Impact of ocean acidification on a key Arctic pelagic mollusc (Limacina helicina), Biogeosciences, 6, 1877-1882, doi:10.5194/bg-6-1877-2009, 2009.

Czerny, J., Schulz, K. G., Boxhammer, T., Bellerby, R. G. J., Büdenbender, J., Engel, A., Krug, S. A., Ludwig, A., Nachtigall, K., Nondal, G., Niehoff, B., Siljakova, A., and Riebesell, U.: Element budgets in an Arctic mesocosm $\mathrm{CO}_{2}$ perturbation study, Biogeosciences Discuss., 9, 11885-11924, doi:10.5194/bgd-911885-2012, 2012a.

Czerny, J., Schulz, K. G., Krug, S. A., Ludwig, A., and Riebesell, U.: Technical Note: On the determination of enclosed water volume in large flexible-wall mesocosms, Biogeosciences Discuss., 9, 13019-13030, doi:10.5194/bgd-9-13019-2012, 2012b.

Czerny, J., Schulz, K. G., Ludwig, A., and Riebesell, U.: Technical Note: A simple method for air-sea gas exchange measurements in mesocosms and its application in carbon budgeting, Biogeosciences, 10, 1379-1390, doi:10.5194/bg-10-1379-2013, 2013.

de Kluijver, A., Soetaert, K., Czerny, J., Schulz, K. G., Boxhammer, T., Riebesell, U., and Middelburg, J. J.: A ${ }^{13} \mathrm{C}$ labelling study on carbon fluxes in Arctic plankton communities under elevated $\mathrm{CO}_{2}$ levels, Biogeosciences, 10, 1425-1440, doi:10.5194/bg-101425-2013, 2013.

Drenner, R. W. and Mazumder, A.: Microcosm experiments have limited relevance for community and ecosystem ecology, Ecology, 80, 1081-1085, 1999.

Eilertsen, H. C., Taasen, J. P., and Weslawski J. M.: Phyto- plankton studies in the fjords of West Spitsbergen: physical environment and production in spring and summer, J. Plankton Res. 11, 12451260, 1989.

Engel, A., Borchard, C., Piontek, J., Schulz, K. G., Riebesell, U., and Bellerby, R.: $\mathrm{CO}_{2}$ increases ${ }^{14} \mathrm{C}$ primary production in an Arctic plankton community, Biogeosciences, 10, 1291-1308, doi:10.5194/bg-10-1291-2013, 2013.

French, R. H. and Watts, R. J.: Performance of in situ microcosms compared to actual reservoir behavior, J. Environ. Eng., 115, 835-849, 1989.

Gattuso, J.-P. and Hansson, L.: Ocean acidification: background and history, in: Ocean acidification, Oxford, edited by: Gattuso, J.-P. and Hansson, L., Oxford University Press, Oxford, 1-20, 2011.

Gattuso, J.-P., Lee, K., Rost, B., and Schulz, K. G.: Approaches and tools to manipulate the carbonate chemistry, in: Guide to best practices in ocean acidification research and data reporting, edited by: Riebesell, U., Fabry, V., Hansson, L., and Gattuso, J.P., Office for Official Publications of the European Communities, Luxembourg, 41-52, 2010.

Hop, H., Pearson, T., Hegseth, E. N., Kovacs, K. M., Wiencke, C., Kwasniewski, S., Eiane, K., Mehlum, F., Gulliksen, B.,
Wlodarska-Kowalczuk, M., Lydersen, C., Weslawski, J. M., Cochrane, S., Gabrielsen, G. W., Leaky, R. J. G., Lønne, O.J., Zajaczkowski, M., Falk-Petersen, S., Kendall, M., Wängberg, S.Å., Bischof, K., Voronkov, A. Y., Kovaltchouk, N. A., Wiktor, J., Poltermann, M., di Prisco, G., Papucci, C., and Gerland, S.: The marine ecosystem of Kongsfjorden, Svalbard, Polar Res., 21, 167-208, 2002.

Hop, H., Falk-Petersen, S., Svendson, H., Kwasniewski, S., Pavlov, V., Pavlova, O., and Søreide, J. E.: Physical and biological characteristics of the pelagic system across Fram Strait to Kongsfjorden, Prog. Oceanogr., 71, 182-231, 2006.

Iversen, K. R. and Seuthe, L.: Seasonal microbial processes in a high-latitude fjord (Kongsfjorden, Svalbard): I. Heterotrophic bacteria, picoplankton and nanoflagellates, Polar. Biol., 34, 731749, 2011.

Kuiper, J., Brockmann, U. H., van het Groenewoud, H., Hoornsman, G., and Hammer, K. D.: Influences of bag dimensions on the development of enclosed plankton communities during POSER, Mar. Ecol. Progr. Ser., 14, 9-17, 1983.

Lischka, S., Büdenbender, J., Boxhammer, T., and Riebesell, U.: Impact of ocean acidification and elevated temperatures on early juveniles of the polar shelled pteropod Limacina helicina: mortality, shell degradation, and shell growth, Biogeosciences, 8, 919-932, doi:10.5194/bg-8-919-2011, 2011.

Lewis, E. and Wallace, D. W. R.: Program developed for $\mathrm{CO}_{2}$ system calculations. ORNL/CDIAC-105, Carbon Dioxide Information Center, Oak Ridge National Laboratory, US Department of Energy, Oak Ridge, Tennessee, 1998.

Menzel, D. W. and Steele, J. H.: The application of plastic enclosures to the study of pelagic marine biota, Rapp. P.-v. Réun. Cons. int. Explor. Mer., 173, 7-12, 1978.

Niehoff, B., Schmithüsen, T., Knüppel, N., Daase, M., Czerny, J., and Boxhammer, T.: Mesozooplankton community development at elevated $\mathrm{CO}_{2}$ concentrations: results from a mesocosm experiment in an Arctic fjord, Biogeosciences, 10, 1391-1406, doi:10.5194/bg-10-1391-2013, 2013.

Petersen, J. E., Kemp, W. M., Bartleson, R., Boynton, W. R., Chen, C.-C., Cornwell, J. C., Gardner, R. H., Hinkle, D. C., Houde, E. D., Malone, T. C., Mowitt, W. P., Murray, L. Sanford, L. P., Stevenson, J. C., Sundberg, K. L., and Suttles, S. E.: Multiscale experiments in coastal ecology: Improving realism and advancing theory, BioScience, 53, 1181-1197, 2003.

Petersen, J. E., Kennedy, V. S., Dennison, W. C., and Kemp, W. M.: Enclosed experimental ecosystems and scale: tools for understanding and managing coastal ecosystems, Springer, New York, 221 pp., 2009

Pilson, M. E. Q. and Nixon, S. W.: Marine microcosms in ecological research, In Microcosms in ecological research, DOE Symposium series 52, Technical information center, US Department of Energy, Washington, DC, 724-741, 1980.

Riebesell, U.: Acid test for marine biodiversity, Nature 454, 46-47, 2008.

Riebesell, U. and Tortell, P.D.: Effects of Ocean Acidification on Pelagic Organisms and Ecosystems, in: Ocean Acidification, edited by: Gattuso, J.-P., Hansson, L., Oxford University Press, 99-121, 2011.

Riebesell, U., Lee, K., and Nejstgaard, J.C.: Pelagic mesocosms, in: Guide to best practices in ocean acidification research and data reporting, edited by: Riebesell, U., Fabry, V., Hansson, L., and 
Gattuso, J.-P., Office for Official Publications of the European Communities, Luxembourg, 81-98, 2010.

Schulz, K. G. and Riebesell, U.: Diurnal changes in seawater carbonate chemistry speciation at increasing atmospheric carbon dioxide, Mar. Biol., doi:10.1007/s00227-012-1965-y, 2012.

Schulz, K. G., Barcelos e Ramos, J., Zeebe, R. E., and Riebesell, $\mathrm{U}$.: $\mathrm{CO}_{2}$ perturbation experiments: similarities and differences between dissolved inorganic carbon and total alkalinity manipulations, Biogeosciences, 6, 2145-2153, doi:10.5194/bg-6-21452009, 2009.

Schulz, K. G., Bellerby, R. G. J., Brussaard, C. P. D., Büdenbender, J., Czerny, J., Engel, A., Fischer, M., Koch-Klavsen, S., Krug, S. A., Lischka, S., Ludwig, A., Meyerhöfer, M., Nondal, G., Silyakova, A., Stuhr, A., and Riebesell, U.: Temporal biomass dynamics of an Arctic plankton bloom in response to increasing levels of atmospheric carbon dioxide, Biogeosciences, 10, 161180, doi:10.5194/bg-10-161-2013, 2013.

Seuthe, L., Iversen, R. K., and Narcy, F.: Microbial processes in a high-latitude fjord (Kongsfjorden, Svalbard): II. Ciliates and dinoflagellates, Polar. Biol., 34, 751-766, 2011.

Silyakova, A., Bellerby, R. G. J., Czerny, J., Schulz, K. G., Nondal, G., Tanaka, T., Engel, A., De Lange, T., and Riebesell, U.: Net community production and stoichiometry of nutrient consumption in a pelagic ecosystem of a northern high latitude fjord: mesocosm $\mathrm{CO}_{2}$ perturbation study, Biogeosciences Discuss., 9, 11705-11737, doi:10.5194/bgd-9-11705-2012, 2012.
Steinacher, M., Joos, F., Frölicher, T. L., Plattner, G.-K., and Doney, S. C.: Imminent ocean acidification in the Arctic projected with the NCAR global coupled carbon cycle-climate model, Biogeosciences, 6, 515-533, doi:10.5194/bg-6-515-2009, 2009.

Svendsen, H., Beszczynska-Møller, A., Hagen, J.O., Lefauconnier, B., Tverberg, V., Gerland, S., Ørbæk, J. B., Bischof, K., Papucci, C., Zajaczkowski, M., Azzolini, R., Bruland, O., Wiencke, C., Winther, J.-G., and Dallmann, W.: The physical environment of Kongsfjorden-Krossfjorden, an Arctic fjord system in Svalbard, Polar Res., 21, 133-166, 2002.

Tanaka, T., Alliouane, S., Bellerby, R. G. B., Czerny, J., de Kluijver, A., Riebesell, U., Schulz, K. G., Silyakova, A., and Gattuso, J.-P.: Effect of increased $p \mathrm{CO}_{2}$ on the planktonic metabolic balance during a mesocosm experiment in an Arctic fjord, Biogeosciences, 10, 315-325, doi:10.5194/bg-10-315-2013, 2013.

Walther, K., Anger, K., and Pörtner, H. O.: Effects of ocean acidification and warming on the larval development of the spider crab Hyas araneus from different latitudes $\left(54^{\circ}\right.$ vs. $\left.79^{\circ} \mathrm{N}\right)$, Mar. Ecol. Progr. Ser., 417, 159-170, 2010.

Wood, H. L., Spicer, J. I., Kendall, M. A., Lowe, D. M., and Widdicombe, S.: Ocean warming and acidification; implications for the Artic brittlestar Ophiocten sericeum, Polar Biol., 34, 1033-1044, doi:10.1007/s00300-011-0963-8, 2011. 